\title{
PARADIGMA PENGENALAN APLIKASI AKUNTANSI DALAM PENYUSUNAN LAPORAN KEUANGAN UMKM
}

\author{
Lestari Kurniawati $^{1)}$ \\ 1) lestari.kurniawati@pknstan.ac.id, Politeknik Keuangan Negara STAN
}

\begin{abstract}
Micro, Small and Medium Enterprises (MSMEs) contribute 60\% of Indonesia's Gross Domestic Product. The number of MSME entrepreneurs also covered 99.99\% of the number of business operators in Indonesia. Data shows that many business actors do not prepare financial statements. This study aims to obtain a picture of the behavior of MSME business practitioners towards the preparation of financial statements as well as responses that emerge from the introduction of aid applications to prepare financial reports. This study uses an interpretive approach to phenomenology. The result of the research shows that the two research objects show different behaviors towards the preparation of financial statements CV Vivo Karya Mandiri has prepared financial reports because there is a need for business continuity. Meanwhile, Kupiku Cafe has not yet prepared financial statements because it does not yet need and there are limited resources. However, both objects gave the same response to the introduction of aid applications to prepare financial statements. The introduction of financial statement preparation assistance applications also succeeded in eroding the perception that it is difficult to prepare financial statements because of the complexity of the process and the difficulty in understanding the meaning, symbols, and numbers in accounting records.
\end{abstract}

Keywords : Accounting applications, financial statements, interpretive paradigms, MSMEs

\begin{abstract}
Abstrak Bahasa Indonesia
Usaha Mikro Kecil dan Menengah (UMKM) memberi kontribusi 60\% dari pendapatan domestik bruto Indonesia. Jumlah pelaku UMKM juga meliput 99,99\% jumlah pelaku usaha di Indonesia. Data menunjukkan bahwa banyak pelaku usaha tidak melakukan penyusunan laporan keuangan. Penelitian ini bertujuan untuk memperoleh gambaran atas perilaku pelaku usaha UMKM terhadap penyusunan laporan keuangan serta respon yang muncul atas pengenalan aplikasi bantuan untuk menyusun laporan keuangan. Penelitian ini menggunakan pendekatan interpretif fenomenologi. Hasi penelitian menunjukkan bahwa kedua obyek penelitian menunjukkan perilaku yang berbeda terhadap penyusunan laporan keuangan CV Vivo Karya Mandiri telah menyusun laporan keuangan karena terdapat kebutuhan demi kelaberangsungan usaha. Sedangkan Kupiku Cafe belum melakukan penyusunan laporan keuangan karena belum membutuhkan dan adanya keterbatasan sumberdaya. Namun demikian kedua obyek memberi respon yang sama atas pengenalan aplikasi bantuan untuk menyusun laporan keuangan. Pengenalan aplikasi bantuan penyusunan laporan keuangan juga berhasil mengikis persepsi bahwa sulit untuk melakukan penyusunan laporan keuangan karena kerumitan proses dan sulit untuk memahami makna, simbol dan angka dalam pencatatan akuntansi.
\end{abstract}

Kata Kunci : Aplikasi Akuntansi, Laporan Keuangan, paradigma interpretif, UMKM

\section{PENDAHULUAN}

Saat ini Usaha Mikro Kecil dan Menengah (UMKM) tengah mendapatkan perhatian besar dunia bisinis maupun pemerintah. Perhatian besar tersebut layak dilakukan mengingat peran UMKM dalam perekonomian Indonesia yang juga besar. Situs ukmindonesia.id dalam sebuah beritanya menyebutkan, secara keseluruhan, kontribusi UMKM terhadap Pendapatan Domestik Bruto Indonesia berada di kisaran angka 60\%. Dari sisi pelaku usaha, UMKM juga mendominasi. Kementerian Koperasi dan UKM menyatakan bahwa pada tahun 2017, pelaku usaha UMKM mencapai 99,99\% atau sebesar 62,9 juta unit usaha dari total pelaku usaha di Indonesia. Sementara dilihat dari penyerapan tenaga kerja, UMKM mampu menyerap 97\% dari jumlah tenaga kerja Indonesia. Porsi terbesar penyerapan tenaga kerja berada di usaha mikro dengan jumlah tenaga kerja terserap mencapai 107,2 juta orang atau sekitar 89,2\% dari total tenaga kerja nasional.

Jumlah pelaku usaha terutama usaha mikro dan kecil bukan merupakan indikasi pertumbuhan tanpa permasalahan. Sebagai usaha yang dirintis sejak awal dengan sumber daya minimal seringkali memiliki berbagai permasalahan yang dapat mengakibatkan tutupnya usaha. Sebagian besar pelaku usaha mikro dan kecil mengeluhkan kurangnya modal dan pemasaran 


\section{JURNALKU}

Volume 1 No. 4, Desember 2021

sebagai persoalan mereka. Dalam sebuah penelitiannya, Suci (2017) menyatakan bahwa UMKM memiliki banyak kelemahan diantaranya kurangnya permodalan baik jumlah maupun sumbernya, kurangnya kemampuan manajerial dan minimnya keterampilan pengoperasi dalam mengorganisir dan terbatasnya pemasaran.

Kelemahan dalam permodalan telah menjadi perhatian pemerintah. Hal tersebut diwujudkan dengan menerbitkan kebijakan Kredit Usaha Rakyat (KUR) sebagai program pemberian pinjaman lunak kepada UMKM. Namun demikian tingkat penyaluran KUR sangat rendah. Hal ini berkebalikan dengan kondisi kurangnya permodalan bagi UMKM. Rudiantoro dan Siregar (2012) menyatakan salah satu penyebab rendahnya penyaluran KUR adalah kehatihatian bank penyalur akibat minimnya informasi memadai atas kondisi keuangan UMKM.

Informasi yang memadai atas kondisi keuangan UMKM dapat diperoleh jika UMKM menyelenggarakan pelaporan keuangan dengan baik dan benar. Penyusunan laporan keuangan yang baik sesuai standar yang berlaku tidak hanya bermanfaat dalam upaya perolehan kredit untuk penambahan modal. Laporan keuangan yang baik dapat memberikan informasi yang tepat atas kondisi keuangan UMKM sehingga dapat mengambil keputusan operasional dengan lebih baik. Dalam berbagai kesempatan laporan keuangan yang baik juga memberikan daya tawar yang lebih tinggi dalam rangka memanfaatkan kesempatan memperluas usaha atau mendapatkan peluang usaha yang baru.

Pada sisi pemerintah, laporan keuangan UMKM yang disusun dengan baik dapat memberikan gambaran pertumbuhan ekonomi mikro dan makro dengan lebih baik. Selain itu informasi tersebut juga dapat memberikan gambaran potensi penerimaan perpajakan dengan lebih baik. Bagi UMKM sendiri, salah satu manfaat yang diperoleh berupa kepastian kewajiban perpajakan dibandingkan dengan kewajiban perpajakan yang muncul hanya berdasarkan omzet usaha. Kewajiban perpajakan merupakan keniscayaan bagi UMKM. Penyusunan laporan keuangan yang baik mampu memberikan kepastian kewajiban perpajakan dengan lebih baik.

Dalam upaya melakukan penyusunan laporan keuangan yang baik dan dapat memberikan informasi yang memadai, UMKM harus mendapat pengetahuan dan ketrampilan yang mendukung. Fakta di lapangan menunjukkan, para pengusaha UMKM lebih fokus pada ketrampilan mengembangkan usahanya dan mengabaikan pentingnya keberadaan laporan keuangan. Penelitian ini disusun untuk mengetahui perilaku pelaku UMKM dalam menyusun laporan keuangan dan respon yang muncul atas pengenalan aplikasi bantuan untuk menyusun laporan keuangan UMKM. Penelitian ini dilakukan melalui depth interview dan sosialisasi aplikasi Akuntansi UKM sebagai alat bantu penyusunan laporan keuangan. Kegiatan tersebut mengambil obyek 2 UMKM, yaitu CV Vivo Karya Mandiri dan Kupiku Cafe.

\section{KAJIAN PUSTAKA}

\section{Usaha Mikro Kecil dan Menengah (UMKM)}

Pemerintah Indonesia melakukan pengaturan terkait UMKM melalui Undang-Undang Nomor 20 tahun 2008 tentang Usaha Mikro, Kecil dan Menengah. Secara umum UMKM didefinisikan sebagai usaha ekonomi produktif milik perseorangan atau badan usaha yang memenuhi kriteria sebagaimana ditetapkan dalam undang-undang. Pasal 6 Undang-Undang Nomor 20 Tahun 2008 mengatur kriteria UMKM sebagaimana disajikan pada Tabel 1 berikut.

Bidang usaha yang ditekuni Usaha Mikro Kecil (UMK) sangat bervariatif. Data Badan Pusat Statistik (BPS) menyebutkan bahwa di bidang non pertanian, bidang usaha perdagangan besar dan eceran, reparasi dan perawatan mobil dan sepeda motor mengambil porsi terbesar sebanyak 46,27\% atau 12.097.326 unit usaha. Di posisi kedua ada bidang usaha penyediaan akomodasi dan penyediaan makan dan minum sebesar $16,93 \%$ dan di posisi ketiga ada industri pengolahan sebesar $16,65 \%$. Selain itu, terdapat 12 bidang usaha lain yang ditekuni UMK dengan porsi masing-masing tidak lebih dari $5 \%$. 
Tabel 1. Kriteria UMKM

\begin{tabular}{|l|l|l|}
\hline \multirow{2}{*}{ Ukuran Usaha } & \multicolumn{1}{|c|}{ Kriteria } \\
\cline { 2 - 3 } & \multicolumn{1}{|c|}{ Aset* } & \multicolumn{1}{|c|}{ Omzet** $^{*}$} \\
\hline Usaha Mikro & Maksimal Rp50 juta & Maksimal Rp300 juta \\
\hline Usaha Kecil & Lebih dari Rp50 juta - Rp500 juta & Lebih dari Rp300 juta - Rp2,5 miliar \\
\hline Usaha & $\begin{array}{l}\text { Lebih dari Rp500 juta - Rp10 } \\
\text { Menengah }\end{array}$ & $\begin{array}{l}\text { Lebih dari Rp2,5 miliar - Rp50 } \\
\text { miliar }\end{array}$ \\
\hline
\end{tabular}

* tidak termasuk tanah dan bangunan tempat usaha

** dalam 1 tahun

Sumber: UU Nomor 20 Tahun 2008, diolah penulis

Undang Undang Nomor 20 Tahun 2008 menyatakan bahwa UMKM bertujuan menumbuhkan dan mengembangkan usahanya dalam rngka membangun perekonomian nasional berdasarkan demokrasi ekonomi yang berkeadilan. Undang-undang ini juga menegaskan bahwa salah satu utujuan pemberdayaan UMKM adalah menumbuhkan dan mengembangkan kemampuan UMKM menjadi usaha yang tangguh dan mandiri. Pasal 7 Undang-Undang nomor 20 Tahun 2008 ini juga menyatakan bahwa Pemerintah dan Pemerintah Daerh menumbuhkan iklim usaha dengan menetapkan peraturan perudang undangan dan kebijakan yang meliputi aspek: pendanaan, sarana prasarana, informasi usaha, kemitraan, perizinan usaha, kesempatan berusaha, promosi dagang, dan dukungan kelembagaan.

Dari aspek pendanaan, Undang- Undang Nomor 20 Tahun 2008 juga mengatur bahwa aspek pendanaan ditujukan diantaranya untuk memperluas sumber pendanaan dan fasilitasi akses kredit, memperbanyak lembaga pembiayaan, memberi kemudahan memperoleh pendanaan, dan membantu memndapatkan pembiayaan dan jasa/produk keuangan lainnya. Hal ini menegaskan bahwa UMKM sebenarnya tidak perlu mengeluhkan soal permodalan karena pemerintah telah berupaya mengatasinya dengan kebijakan seperti Kredit Usaha Rakyat. Namun demikian sebagaimana transaksi bisnis yang berasa kepercayaan, akses kredit juga memerlukan kepercayaan dari bank ataupun lembaga keuangan yang memberikan pinjaman. Kepercayaan bank/lembaga keuangan dapat terbentuk apabila didukung dengan laporan keuangan yang memadai. Persepsi para pelaku UMKM yang meyakini bahwa sulit untuk menyusun laporan keuangan berdampak pada sulitnya UMKM untuk mendapatkan akses kredit permodalan.

\section{Laporan Keuangan}

Pernyataan Standar Akuntansi Keuangan (PSAK) 1 menyatakan bahwa laporan keuangan yang lengkap terdiri dari: laporan posisi keuangan, laporan laba rugi, laporan perubahan ekuitas, laporan arus kas, dan catatan atas laporan keuangan. Kieso (2018, 70) menyatakan bahwa tujuan umum penyusunan laporan keuangan adalah untuk menyediakan informasi keuangan yang bermanfaat dari suatu entitas usaha untuk disajikan kepada calon investor dan kreditor yang potensial. Pernyataan tersebut dilandasi oleh jumlah pengguna terbesar laporan keuangan adalah investor dan kreditur. Meski pengguna terbesar laporan keuangan adalah investor dan kreditur, pengguna internal sperti manajemen juga dapat memanfaatkan informasi tersebut untuk mengambil keputusan terkait operasional entitas usaha.

Pengambil keputusan baik internal maupun eksternal dapat melihat bagaimana posisi keuangan seperti jumlah aset, utang dan modal suatu entitas usaha melalui laporan posisi keuangan. Sedangkan kinerja keuangan entitas usaha dapat dilihat pada laporan laba rugi yang memberi gambaran bagaimana kinerja entitas usaha untuk menghasilkan laba. Dari sisi perolehan kas, para pengambil keputusan dapat melihat bagaimana kas masuk dan kas keluar dari entitas perusahaan melalui laporan arus kas. Sementara untuk melihat bagaimana modal suatu entitas usaha terbentuk dan bertransformasi dapat dilihat melalui laporan perubahan 


\section{JURNALKU}

Volume 1 No. 4, Desember 2021

ekuitas. Untuk melengkapi informasi yang telah disajikan dalam 4 jenis laporan tersebut, entitas usaha membuat catatan atas laporan keuangan yang berisi informasi atas perlakuan akuntansi yang digunakan pada 4 jenis laporan tersebut.

Dalam penyusunan laporan keuangan, suatu entitas usaha harus membuat asumsi agar pembaca laporan keuangan mendapat satu pemahaman utuh. Asumsi yang digunakan meliputi: dasar akrual, satu entitas ekonomi, keberlanjutan, unit moneter, dan periodesitas. Dasar akrual berarti suatu entitas usaha akan melaporkan transaksi keuangannya pada saat transaksi tersebut terjadi. Hal ini berarti pencatatan tidak tergantung pada kapan diterima atau dikeluarkan kas dari entitas usaha. Pada asumsi satu entitas ekonomi dimaksudkan bahwa pelaporan keuangan yang disusun merupakan satu entitas usaha tersendiri tidak tergabung dengan entitas usaha lain ataupun pemilik usaha. Pada asumsi ini harus terjadi pemisahan kepemilikan antara entitas usaha dengan pemilik usaha. Sedangkan asumsi keberlanjutan berarti bahwa pelaporan disusun seakan-akan entitas usaha akan terus berjalan selamanya. Asumsi unit moneter diperlukan agar penyusunan laporan keuangan menggunakan satu unit moneter tertentu yang secara konsisten dipergunakan dalam penyusunan laporan keuangan. Pada asumsi periodesitas diharapkan entitas usaha dapat menyusun laporan keuangan berdasarkan periode tertentu dan secara konsisten dilakukan.

Selain penggunaan asumsi, dalam pencatatan dan penyusunan laporan keuangan juga harus menerapkan prinsip akuntansi. International Accounting Standard Board (IASB) menyatakan prinsip akuntansi yang digunakan adalah: pengukuran, pengakuan pendapatan dan beban, dan penyajian secara lengkap. Dalam menyusun laporan keuangan, suatu entitas usaha harus melakukan pengukuran agar dapat menyajikan suatu nilai dalam laporan keuangan. Tedapat dua jenis ukuran yang dapat digunakan dalam mengukur transaksi keuangan, yaitu biaya historis dan nilai wajar. Keduanya dapat digunakan sesuai dengan karakteristik transaksi keuangan yang terjadi. Pada prinsip pengakuan pendapatan, suatu entitas harus mengakui pendapatan pada periode dimana pendapatan tersebut terjadi. Jika pendapatan terjadi secara bertahap maka pengakuan pendapatan juga dilakukan secara bertahap. pengakuan pendapatan yang dilakukan secara bertahap juga tidak tergantung dengan penerimaan kas. Pendapatan diakui ketika kewajiban selesai dilaksanakan bukan ketika entitas usaha menerima kas. Pengakuan pendapatan sejalan dengan pengakuan beban. Dalam prinsip pengakuan beban, suatu entitas usaha dapat melakukan pengakuan beban pada periode dimana entitas usaha mengakui pendapatan. Pada prinsip pengungkapan penuh, suatu entitas usaha diminta untuk menyajikan informasi-informasi yang dianggap penting yang dapat berpengaruh terhadap pengambilan keputusan.

\section{Laporan Keuangan Pada UMKM}

Dalam rangka mendukung pemberdayaan UMKM, Ikatan Akuntan Indonesia (IAI) telah menerbitkan Standar Akuntansi Keuangan Entitas Tanpa Akuntabilitas Publik (SAK ETAP). Penerbitan SAK ETAP pada bulan Mei 2009 dimaksudkan untuk membantu UMKM melakukan penyusunan laporan keuangan. Perhatian dunia terhadap usaha kecil dan menengah terutama terkait pelaporan keuangannya telah diwujudkan melalui penerbitan discussion paper tentang standar akuntansi untuk usaha kecil dan menengah. Penerbitan standar akuntansi tersebut sangat membantu usaha kecil dan menengah karena lebih mudah dipahami dan dilaksanakan. Hal ini didukung oleh hasil penelitian Pinasti (2007) dalam Zuhdi (2011) yang menyatakan bahwa banyak pengusaha kecil yang merasa kerepotan ketika harus menggunakan informasi akuntansi dalam melaporkan usaha mereka. Hal ini dapat dimaklumi mengingat sebagian besar usaha kecil dan menengah mempunyai sumber daya baik manusia, modal, dan pemahaman yang terbatas. Penyederhanaan standar akuntansi yang ditujukan untuk UMKM diharapkan mampu menarik minat para pelaku UMKM untuk melakukan pencatatan dan pelaporan keuangan. 


\section{JURNALKU}

Volume 1 No. 4, Desember 2021

Meski merupakan penyederhanaan dari Standar Akuntansi Keungan (SAK) namun secara substansi tidak terdapat perbedaan yang sangat signifikan. Hal ini dilakukan agar informasi keuangan yang disajikan tetap dapat memenuhi ketentuan relevan dan jujur. Perbedaan yang terlihat menonjol pada SAK ETAP apabila dibandingkan dengan SAK adalah adanya pengurangan yang cukup signifikan terhadap persyaratan penyajian laporan keuangan. Secara garis besar perbedaan yang muncul antara SAK ETAP dan SAK terletak pada pengungkapannya. Selain itu pada metode pelaporan arus kas, SAK ETAP hanya menggunakan metode indirect methode. Selain itu, dalam pelaporan investasi menerapkan standar US GAAP bukan IFRS. Perbedaan lain muncul pada pengukuran aset tetap, SAK ETAP lebih menekankan pada metode biaya, metode revaluasi dapat digunakan sepanjang terdapat aturan dari pemerintah. Pada sisi borrowing cost, perlakuan SAK ETAP juga berbeda. SAK ETAP memperlakukan borrowing cost sebagai beban sementara pada SAK, borrowing cost dikapitalisasi.

\section{METODE}

Penelitian ini menggunakan paradigma interpretif dengan pendekatan fenomenologi. Neuman (2003) menyebutkan bahwa penelitian interpretif merupakan sebuah analisis secara mendalam dan sistematis terhadap suatu tindakan bermakna sosial yang dilaksanakan melalui observasi langsung secara mendetail dari objek studi pada setting alamiahnya. Hal ini dilakukan untuk memperoleh sebuah pemahaman bagaimana suatu lingkungan sosial tercipta dan bekerja. Ernams (2008) menyatakan bahwa paradigma interpretif dapat digunakan untuk melihat fenomena dan menggali pengalaman serta pemahaman dari objek penelitian. Pendekatan interpretif muncul sebagai upaya untuk mencari penjelasan atas peristiwa sosial budaya berdasar perspektif dari pengalaman orang yang diteliti.

Pendekatan interpretif fenomenologi digunakan dengan tujuan untuk mengumpulkan dan melakukan analisa data agar dapat mengarah pada pemahaman atas makna dari interpretasi manusia sebagai respon terhadap fenomena sosial. Dalam penelitiannya Chua (1986) menyatakan penyusunan laporan keuangan sebagai fenomena sosial mempunyai konsekuensi berupa: 1) informasi akuntansi dapat diberi atribut/makna yang berbeda, 2) selain makna akuntansi yang diterapkan oleh struktur, ditetapkan pula realitas sosial yang diobjektifikasi, dan 3) informasi akuntansi tidak hanya digunakan sebagai alat untuk mencapai tujuan yang telah ditetapkan.

Penelitian ini mencoba untuk melihat bagaimana perilaku pelaku UMKM dalam melakukan penyusunan laporan keuangannya serta respon atas pengenalan aplikasi pencatatan dan pelaporan keuangan berbasis android. Obyek dalam penelitian ini adalah dua UMKM di kawasan Tangerang Selatan. CV Vivo Karya Mandiri merupakan sebuah usaha yang bergerak di bidang jasa multimedia. CV Vivo Karya Mandiri pada awalnya merupakan usaha perorangan yang berdiri pada bulan Oktober 2014. Pemilik usaha memiliki latar belakang Pendidikan perguruan tinggi. Usaha yang berada di wilayah Pondok Aren Tangerang Selatan ini kemudian berkembang dan beralih menjadi persekutuan komanditer (CV). Dengan bentuk usaha CV, 60\% kepemilikan usaha ini dikuasai oleh pendiri sekaligus direktur utama. Saat ini CV Vivo Karya Mandiri memiliki 7 (tujuh) orang karyawan dengan omzet rata-rata per tahun mencapai Rp2 miliar.

Obyek penelitian lainnya adalah Kupiku Cafe. Entitas usaha ini dimiliki oleh perseorangan dengan latar pendidikan perguruan tinggi. Kupiku café bergerak dalam bidang usaha makanan dan minuman. Saat ini Kupiku Cafe mempekerjakan 6 orang karyawan. Berdasarkan informasi omzet yang dihasilkan, entitas usaha ini termasuk usaha mikro. Meski termasuk usaha mikro, namun aset Kupiku Cafe cukup besar. Hal ini dapat dilihat dari penggunaan lahan dan gedung dalam menjalankan bisnisnya. Lahan dan gedung bangunan 


\section{JURNALKU}

Volume 1 No. 4, Desember 2021

berada di lokasi yang strategis dengan luasan cukup besar dan merupakan milik Kupiku Café sendiri.

\section{HASIL DAN PEMBAHASAN \\ Penyusunan Laporan Keuangan}

Berdasarkan data dan informasi yang diperoleh selama penelitian, kedua obyek penelitian memiliki perilaku yang berbeda dalam melaksanakan penyusunan laporan keuangan berbeda. CV Vivo Karya Mandiri telah melakukan penyusunan laporan keuangan. Penyusunan laporan keuangan dilakukan secara manual dengan alat bantu Microsoft Excell. Penyusunan laporan keuangan dengan bantuan Microsoft Excell yang dilakukan saat ini masih mengalami kendala. Permasalahan yang sering muncul adalah kerepotan untuk melakukan posting transaksi agar dapat menghasilkan laporan keuangan. Permasalahan lain yang muncul adalah keterbatasan penguasaan Microsoft Excell sehingga proses pencatatan dan penyusunan laporan keuangan cenderung lama dan menghabiskan tenaga. Selain itu pergantian personil yang melakukan pencatatan memunculkan persoalan tersendiri. Pada pergantian personil, akselerasi proses pencatatan dan penyusunan laporan keuangan cenderung lambat. Entitas usaha harus memberikan pelatihan dan pemahaman kembali kepada personil baru terkait proses pencatatan dan pelaporan keuangan.

Meski mengalami berbagai hambatan dan permasalahan terkait pencatatan dan pelaporan keuangan, CV Vivo Karya Mandiri tetap melakukan penyusunan laporan keuangan. Hal ini diperlukan mengingat sebagian besar pelanggan CV Vivo Karya Mandiri adalah institusi pemerintahan. Dalam berbagai transaksi dengan institusi pemerintahan, laporan keuangan seringkali menjadi prasyarat untuk menunjukkan kinerja.

Bagi sebuah entitas usaha yang melakukan transaksi dengan institusi pemerintahan, laporan keuangan menjadi wajib untuk disajikan. Dalam melakukan transaksi dengan pihak eksternal institusi pemerintahan cenderung mencari entitas usaha yang terpercaya dan telah melakukan kewajiban perpajakannya. Kepercayaan terhadap entitas usaha salah satunya diwujudkan dengan melihat bagaimana entitas usaha melakukan pelaporan keuangannya. Hal ini juga terkait dengan pembayaran kewajiban perpajakannya. entitas usaha yang telah melaksanakan pelaporan keuangan cenderung menjadi wajib pajak yang patuh untuk melaporkan dan melakukan pembayaran kewajiban perpajakannya. Saat ini CV Vivo Karya Mandiri mempunyai omzet rata-rata per tahun sebesar Rp2 miliar. Dengan jumlah omzet tersebut, CV Vivo Karya Mandiri termasuk dalam kriteria usaha kecil.

Peraturan Pemerintah (PP) Nomor 23 Tahun 2018 mengatur kewajiban perpajakan bagi wajib pajak yang memiliki peredaran bruto (omset) sampai dengan Rp4,8 miliar rupiah. PP Nomor 23 Tahun 2018 merupakan perubahan atas PP Nomor 46 Tahun 2013. Perubahan yang terjadi diantaranya adalah adanya penurunan tarif $\mathrm{PPh}$ Final atas penghasilan bruto tertentu dari semula $1 \%$ menjadi $0,5 \%$ dari omzet. Penurunan tarif $\mathrm{PPh}$ final juga dilakukan sebagai upaya untuk menarik UMKM untuk patuh terhadap kewajiban perpajakan. Penggunaan omzet sebagai dasar pengenaan pajak juga dimaksudkan sebagai simplifikasi perhitungan kewajiban perpajakan. Hal ini dilakukan mengingat sebagaian besar UMKM belum menyelenggarakan pelaporan keuangan sehingga sulit melakukan perhitungan kewajiban perpajakan.

Penggunaan omzet sebagai dasar pengenaan pajak memiliki kelemahan. Omzet tidak mencerminkan laba operasi usaha, sehingga terdapat kemungkinan meski mengalami kerugian, pelaku UMKM tetap diharuskan membayar kewajiban perpajakannya. Hal ini disadari oleh Pemerintah dan kemudian ditindaklanjuti dengan pengaturan pada Pasal 5 PP Nomor 23 tahun 2018 tentang jangka waktu pengenaan pajak penghasilan yang bersifat final tersebut, yaitu: 1) bagi wajib pajak orang pribadi diberi jangka waktu paling lama 7 tahun, 2) bagi wajib pajak badan berbentuk koperasi, persekutuan komanditer atau firma paling lama 4 tahun, dan 3) bagi 


\section{JURNALKU}

Volume 1 No. 4, Desember 2021

wajib pajak badan berbentuk perseroan terbatas paling lama 3 tahun. Peraturan ini sekaligus menegaskan bahwa pencatatan dan pelaporan keuangan merupakan sebuah kewajiban bagi entitas usaha.

Kewajiban pencatatan dan pelaporan keuangan diatur dalam Pasal 28 Undang-Undang Ketentuan Umum Perpajakan. Pasal 28 Undang-Undang Ketentuan Umum Perpajakan menyatakan bahwa wajib pajak orang pribadi yang melakukan kegiatan usaha atau pekerjaan bebas dan wajib pajak badan di Indonesia wajib menyelenggarakan pembukuan. Pengaturan dalam Undang-Undang Ketentuan Umum Perpajakan tidak bertentangan dengan PP Nomor 23 Tahun 2018. Ketentuan dalam PP Nomor 23 Tahun 2018 memberikan waktu transisi bagi UMKM untuk melakukan persiapan dan sekaligus pembelajaran bagi UMKM untuk menyusun laporan keuangan. Pembatasan waktu bagi wajib pajak memberi penegasan bahwa semua wajib pajak sudah harus siap melaksanakan pembukuan pada saat batas waktu mencapai akhir.

Kewajiban entitas usaha untuk melaksanakan pembukuan bukan hanya tuntutan dari regulasi perpajakan. Namun penyusunan laporan keuangan juga memberikan manfaat bagi entitas usaha. Entitas usaha yang telah melakukan penyusunan laporan keuangan mempunyai kesempatan yang lebih besar untuk mengakses kredit usaha dari lembaga keuangan maupun perbankan. Selain itu laporan keuangan yang tersusun dapat memberikan informasi posisi dan kinerja keuangan dari entitas usaha. Informasi ini dapat bermanfaat dalam pengambilan keputusan operasional entitas usaha. Dalam banyak kasus seringkali terjadi suatu usaha ditutup dengan alasan modalnya habis. Hal ini kadang menjadi tidak logis jika pada faktanya omzet usaha tersebut tinggi. Penutupan usaha dapat terjadi ketika tidak terjadi pemisahan kepemilikan aset antara entitas usaha dan pemilik. Tidak adanya pencatatan dapat berdampak pemilik usaha mengambil uang kas lebih besar daripada laba yang dihasilkan. Hal ini kemudian berdampak pada tergerusnya modal usaha sehingga usaha mengalami kebangkrutan.

CV Vivo Karya Mandiri sebagai sebuah entitas usaha dengan bentuk persekutuan komanditer harus melakukan pencatatan dengan benar seluruh transaksi keuangannya. Hal ini dilakukan mengingat entitas usaha tidak hanya dimiliki oleh satu orang sehingga pengelola usaha harus secara transparan dan akuntabel melaporkan kondisi keuangan entitas usaha. Meski laporan keuangan yang diterbitkan saat ini masih berupa laporan posisi keuangan dan laporan laba rugi, CV Vivo Karya Mandiri telah memenuhi asumsi dan prinsip dalam pencatatan transaksi keuangan sehingga informasi yang disajikan dapat dimanfaatkan oleh pembaca laporan keuangan. Pada saat ini, meski terdapat hambatan dan permasalahan dalam penyusunan laporan keuangan, CV Vivo Karya Mandiri menganggap penyusunan laporan keuangan adalah sebuah kebutuhan yang mendukung keberlangsungan usaha.

Hal ini berbeda dengan perlakuan Kupiku Café terhadap penyusunan laporan keuangan. Pemilik Kupiku Cafe membuat kebijakan untuk mencatat transaksi penjualan dan diintegrasikan untuk disimpan di $i$-cloud. Namun demikian pencatatan yang dilakukan terbatas penjualan dan pembelian bahan baku. Pembelian bahan baku dicatat sendiri oleh pemilik dan disimpan di i-cloud. Atas data-data tersebut, pemilik leluasa mengakses catatan transaksi penjualan namun transaksi pembelian bahan baku mempunyai akses yang terbatas. Proses pencatatan tersebut dirasa sangat kurang memadai bagi pemilik café. Selain itu, pencatatan yang dilakukan juga tidak memenuhi asumsi dan prinsip dasar dalam melakukan pencatatan dan penyusunan laporan keuangan. Hal ini berakibat pada informasi yang disajikan tidak lengkap dan tidak relevan untuk dapat dimanfaatkan oleh pemilik café ataupun pihak luar.

Terbatasnya informasi yang disajikan oleh proses pencatatan transaksi tersebut menyebabkan pemilik café tidak dapat menerbitkan laporan keuangan. Berdasarkan informasi yang diperoleh, pemilik café memilih untuk menunda penyusunan laporan keuangan karena merasa informasi yang terbatas tersebut sudah cukup meski belum memadai. Dalam hal ini, pemilik café sebenarnya menyadari bahwa pencatatan akuntansi yang baik dan penyusunan 


\section{JURNALKU}

Volume 1 No. 4, Desember 2021

laporan keuangan sangat penting bagi bisnis, namun adanya keterbatasan dan tidak adanya tuntutan atas penerbitan laporan keuangan menjadikan pemilik café memilih untuk menunda penyusunan laporan keuangan.

Penundaan penyusunan laporan keuangan ini bukan tanpa alasan. Pemilik café merasa belum mempunyai pemahaman yang cukup untuk melakukan penyusunan laporan keuangan. Pemilik café merasa sulit untuk memahami makna, simbol dan angka dalam akuntansi. Pemilik café juga merasa proses pencatatan dan penyusunan laporan keuangan sulit untuk dilakukan. Aplikasi-aplikasi bantuan untuk menyusun laporan keuangan juga dirasa sulit untuk dipahami dan diaplikasikan. Sampai dengan saat ini, pemilik café juga belum dapat mempercayakan tugas untuk melakukan pencatatan akuntansi dan penyusunan laporan keuangan kepada pegawainya. Terbatasnya jumlah pegawai dan kapasitas pegawai Kupiku Cafe juga turut mendukung keputusan pemilik café.

Pada sebagian entitas usaha motivasi penyusunan laporan keuangan muncul karena ada tuntutan untuk memenuhi persyaratan pengajuan kredit pembiayaan. Kondisi ini tidak terjadi pada pemilik Kupiku Cafe. Selama ini belum ada rencana penambahan modal dari pembiayaan luar sehingga tidak ada kewajiban untuk menyusun laporan keuangan. Selain itu, Kupiku Cafe juga merupakan usaha pribadi perorangan sehingga tidak ada tuntutan untuk menyajikan laporan keuangan kepada pihak lain selaku investor. Terhadap kewajiban perpajakannya, pemiliki Kupiku Cafe memilih untuk menghitung kewajiban perpajakannya berdasar omzet sebagaimana PP Nomor 23 Tahun 2018.

Secara garis besar, perilaku pemilik Kupiku Cafe untuk tidak melakukan penyusunan laporan keuangan didorong oleh persepsi bahwa sulit untuk melakukan penyusunan laporan keuangan. Perilaku tersebut juga didukung dengan perasaan tidak ada tuntutan/kebutuhan untuk menyusun laporan keuangan. Tingginya pendidikan pemilik café, membuat pemilik café menyadari arti penting penyusunan laporan keuangan. Usaha-usaha untuk melakukan penyusunan laporan keuangan sebenarnya sudah dilakukan oleh pemilik café. Beberapa usaha yang telah dilakukan adalah mengikuti pelatihan akuntansi, belajar memahami akuntansi secara autodidak hingga mencoba mencari aplikasi bantuan untuk melakukan penyusunan laporan keuangan. Namun hingga sekarang, pemilik café masih beranggapan bahwa penyusunan laporan keuangan sulit untuk dilakukan. Pemilik café masih berharap menemukan satu aplikasi bantuan untuk menyusun laporan keuangan yang mudah untuk digunakan dan menggunakan istilah yang mudah dipahami.

\section{Pengenalan Aplikasi UKM untuk Penyusunan Laporan Keuangan}

Dalam penelitian ini, dua obyek memiliki sikap yang berbeda terhadap penyusunan laporan keuangan. Pada CV Vivo Karya Mandiri, penyusunan laporan keuangan dilakukan dalam rangka menyajikan informasi keuangan yang komprehensif. Sementara Kupiku Cafe tidak melakukan penyusunan laporan keuangan dan informasi keuangan diperoleh secara parsial berdasarkan arus kas keluar. Kualitas dan tingkat kebermanfaatan informasi keuangan yang disajikan juga berbeda. Namun kedua-dua perlakuan tersebut muncul karena tingkat kebutuhan yang berbeda.

Pada CV Vivo Karya Mandiri meski telah melakukan penyusunan laporan keuangan namun laporan yang disusun belum lengkap. Dengan bantuan Microsoft Excell, CV Vivo Karya Mandiri berhasil menyusun laporan posisi keuangan dan laporan laba rugi namun belum berhasil menyusun laporan arus kas dan laporan perubahan ekuitas. Dengan demikian selain masih mengalami kendala terkait sumber daya manusia dan pemahaman alat, CV Vivo Karya Mandiri juga membutuhkan usaha lagi untuk melengkapi laporan keuangannya. Sementara itu, Kupiku Cafe meski belum merasa sangat membutuhkan penyusunan laporan keuangan, pemilik telah menyadari bahwa entitas usaha perlu untuk melakukan penyusunan laporan keuangan. 


\section{JURNALKU}

Volume 1 No. 4, Desember 2021

Namun demikian karena keterbatasan sumber daya, pemilik lebih memilih untuk menunda penyusunan laporan keuangan.

Pada dua kondisi tersebut, kedua UMKM memberikan respon yang sama terhadap pengenalan aplikasi penyusunan laporan keuangan. Dalam penelitian ini, aplikasi yang diperkenalkan adalah aplikasi Akuntansi UKM. Aplikasi tidak berbayar ini berbasis Android dengan bahasa pengantarnya adalah bahasa Indonesia. Aplikasi ini juga dilengkapi dengan petunjuk penggunaannya. Aplikasi Akuntansi UKM menerapkan Sistema aplikasi sederhana sehingga cocok untuk digunakan oleh UMKM. Dengan tingkat Pendidikan pelaku UMKM yang beragam dan keterbatasan kapasitas, aplikasi UKM Akuntansi menjadi rekomendasi karena kemudahan dalam pengoperasiannya. fitur-fitur dan menu yang ada di dalamnya termasuk friendly user bagi para pemegang gawai.

Aplikasi Akuntansi UKM memungkinkan para pelaku UKM melakukan pencatatan transaksi keuangan harian. Transaksi keuangan yang diinput dalam jurnal harian secara otomatis akan terposting di buku besar sehingga dapat menghasilkan laporan keuangan. Hanya saja laporan keuangan yang terbentuk dari aplikasi ini juga masih sederhana berupa laporan posisi keuangan dan laporan laba rugi. Namun demikian laporan ini sudah dapat membantu para pelaku UMKM untuk melakukan pencatatan dan pelaporan keuangan pada tahap awal. Pada tahap berikutnya jika hendak memenuhi kualifikasi laporan keuangan sesuai SAK ETAP maka entitas usaha dapat menyusun laporan arus kas, laporan perubahan modal dan catatan atas laporan keuangan berdasar pencatatan yang telah dilakukan. Tujuan utama pembuatan aplikasi Akuntansi UKM adalah untuk menarik para pelaku UMKM melakukan pencatatan transaksi keuangannya sehingga aplikasi ini didesain sangat sederhana dan user friendly. Pencatatan transaksi keuangan entitas usaha paling tidak berguna bagi entitas usaha untuk meminimalisir resiko kebangkrutan.

Setelah dilakukan pengenalan aplikasi Akuntansi UKM, baik CV Vivo Karya Mandiri maupun Kupiku Cafe menyambuat baik dan anthusias terhadap aplikasi tersebut. Bagi CV Vivo Karya Mandiri, aplikasi ini dapat menyelesaikan permasalahan sulitnya menggunakan Microsoft Excell dalam penyusunan laporan keuangan. Aplikasi ini mudah dipahami dan digunakan oleh siapa saja sehingga jika terjadi pergantian pegawai yang bertugas melakukan pencatatan transaksi keuangan, proses akselerasinya akan lebih cepat. Meski aplikasi ini belum dapat menyusun laporan arus kas dan laporan perubahan modal, namun aplikasi ini dirasa cukup untuk memenuhi kebutuhan CV Vivo Karya Mandiri saat ini.

Sambutn yang sama jug dilkukan oleh pemilik Kupiku Cafe. Kemudahan penggunaan, fitur-fitur yang familiar, dan basis android menarik pemilik Kupiku Cafe untuk menggunakan aplikasi ini. Selain dapat menyusun laporan laba rugi dan laporan posisi keuangan, aplikasi Akuntansi UKM juga dapat menampilkan posisi hutang maupun piutang entitas usaha. Bagi entitas usaha perseorangan, hal ini penting untuk memberikan warning alert atas posisi utang piutang entitas usaha. Aplikasi ini juga mampu menerbitkan laporan SPT Tahunan PPh Orang Pribadi. Fitur ini memudahkan pemilik usaha perseorangan untuk menghitung kewajiban perpajakannya.

Dengan segala kelebihan dan manfaat aplikasi, Kupiku Cafe masih mengalami kendala untuk memulai menggunakan aplikasi ini. Salah satu kendala yang muncul adalah belum adanya data aset yang dimiliki oleh entitas usaha. Aset yang dimiliki Kupiku Cafe cukup besar mengingat segala aset yang berada di tempat usaha merupakan aset yang dimiliki oleh pemilik dan dianggap sebagai aset Kupiku Cafe. Untuk dapat menyusun laporan keuangan entitas usaha, Kupiku Cafe harus melakukan identifikasi dan penilaian aset yang dimiliki sebagai saldo awal usaha. Bagi entitas usaha yang telah berjalan, penilaian aset merupakan pekerjaan besar. Hal ini terjadi karena aset yang ada sekarang nilainya sudah tidak sama dengan nilai ketika entitas usaha membeli aset tersebut. Agar dapat menyajikan informasi yang relevan, entitas 


\section{JURNALKU}

Volume 1 No. 4, Desember 2021

usaha harus melakukan revaluasi aset berdasar nilai wajarnya. Opsi lain adalah menggunakan nilai biaya historis. Pada opsi ini, entitas usaha harus mendata ulang nilai pembelian aset dan menentukan nilai penyusutannya. Nilai pembelian aset dikurangi dengan akumulasi penyusutannya dapat menampilkan nilai aset yang dimiliki saat ini. Dua opsi ini sama-sama membutuhkan usaha yang besar dari pemilik Kupiku Cafe. Namun demikian opsi penggunaan nilai wajar lebih direkomendasikan karena menampilkan nilai pasar aset saat ini. Penggunaan nilai wajar dapat memberikan informasi keuangan yang lebih relevan.

Permasalahan tersebut tidak ditemukan pada CV Vivo Karya Mandiri. Peralihan dari pembukuan manual dengan Microsoft Excell menjadi pembukuan dengan menggunakan aplikasi Akuntansi UKM dapat lebih mudah dilakukan CV Vivo Karya Mandiridapat menggunakan laporan keuangan terakhir sebagai saldo awal dan melakukan pencatatan transaksi melalui input jurnal harian. Adanya pegawai yang khusus bertugas melakukan pencatatan transaksi keuangan juga mempermudah hal tersebut.

\section{PENUTUP \\ Simpulan}

Penyusunan laporan keuangan merupakan suatu proses yang dilaksanakan untuk menghasilkan informasi keuangan yang bermanfaat bagi para pengambil keputusan. Agar dapat melakukan proses ini, entitas usaha terlebih dahulu harus melakukan identifikasi, klasifikasi, pencatatan, posting dan penyesuaian (jika diperlukan) atas transaksi-transaksi keuangan yang terjadi pada entitas usaha. Pada sebagian besar pelaku usaha, penyusunan laporan keuangan identic dengan akuntansi yang berisi angka dan symbol. Pemahaman atas angka dan symbol serta proses perlakuan akuntansi yang membatasi pelaku usaha untuk melakukan penyusunan laporan keuangan. Pada dua obyek penelitian ini, kedua informan menyadari arti pentingnya penyusunan laporan keuangan. Namun demikian perlakuan yang muncul dari keduanya berbeda.

CV Vivo Karya Mandiri melakukan penyusunan laporan keuangan karena berada pada tahap membutuhkan laporan keuangan sebagai bentuk pertanggungjawaban untuk keberlangsungan usaha. Sementara Kupiku Cafe meski menyadari arti penting penyusunan laporan keuangan, namun demikian keterbatasan dalam memahami simbol dan angka serta proses akuntansi selalu mengarahkan pemilik untuk menunda penyusunan laporan keuangan.

Pengenalan aplikasi Akuntansi UKM sebagai alat bantu untuk melakukan pencatatan akuntansi hingga penyusunan laporan keuangan menimbulkan satu persepsi baru bagi informan bahwa penyusunan laporan keuangan bisa dan mudah untuk dilakukan. Meski belum ada pada tahap eksekusi penggunaan aplikasi, namun niat untuk melakukan penyusunan laporan keuangan dengan aplikasi ini telah timbul. Fitur-fitur yang familiar dan kemudahan penggunaan (user friendly) menjadi motor utama yang menarik pelaku UMKM untuk menggunakan aplikasi ini. Munculnya aplikasi ini juga mengikis persepsi bahwa sulit untuk memahami makna, simbol dan angka akuntansi dalam penyusunan laporan keuangan.

\section{Saran}

Hasil penelitian ini memberi gambaran bahwa pada dasarnya pemilik UMKM dengan tingkat pendidikan tinggi menyadari pentingnya menyelenggarakan pencatatan dan menyusun laporan keuangan. Namun demikian keterbatasan pemahaman maupun sumber daya untuk melakukan pencatatan dan penyusunan laporan keuangan menghambat keinginan untuk menyusun laporan keuangan. Penelitian ini memiliki keterbatasan hanya menggunakan dua narasumber dengan bidang usaha yang berbeda. Periode penelitian juga sangat singkat, hanya sampai pada tahap pengenalan aplikasi tidak mendampingi. Pada penelitian selanjutnya, periode waktu dapat diperpanjang hingga pendampingan dan perluasan informan. Selain itu, 


\section{JURNALKU}

Volume 1 No. 4, Desember 2021

penelitian juga dapat difokuskan pada faktor yang memotivasi bukan hambatan penyusunan laporan keuangan.

\section{DAFTAR PUSTAKA}

Chua, W. F. (1986). Radical Developments in Accounting Thought. The Accounting Review, $61(4), 601$.

Ernams. 2008. Paradigm of Interpretive Approach. Online collection of language and literature articles. http://www. wikipedia. org/methodology_ research/interpretation downloaded on September 13, 2012.

Ikatan Akuntan Indonesia 2012, Standar Akuntansi Keuangan per 1 Juli 2012. Salemba Empat, Jakarta.

Kieso, D. E., Weygandt, J. J., \& Warfield, T. D. (2018). Intermediate Accounting IFRS. Edition (USA: Wiley).

Neuman, S. B., \& Dickinson, D. K. (Eds.). (2003). Handbook of early literacy research (Vol. 1). Guilford Press.

Peraturan Pemerintah Nomor 23 Tahun 2018 Tentang Pajak Penghasilan Atas Penghasilan Dari Usaha Yang Diterima Atau Diperoleh Wajib Pajak Yang Memiliki Peredaran Bruto Tertentu. Diakses dari situs (www. hukumonline. com) pada tanggal, 13 Agustus 2019.

Republik Indonesia, Undang Undang Nomor 20 Tahun 2008 tentang Usaha Mikro. Kecil, dan Menengah.

Rudiantoro, R., \& Siregar, S. V. (2012). Kualitas laporan keuangan umkm serta prospek implementasi SAK ETAP. Jurnal Akuntansi dan Keuangan Indonesia, 9(1), 1-21.

Suci, Y. R. (2017). Perkembangan UMKM (Usaha mikro kecil dan menengah) di Indonesia. Cano Ekonomos, 6(1), 51-58.

WinFeel Indonesia, 21 Desember 2014. Aplikasi Akuntansi untuk UKM Indonesia Gratis! https://www.kompasiana.com/wiinfeel/aplikasi-akuntansi-untuk-ukm-indonesiagratis_54f91f79a3331176038b476f. Diakses pada 14 Agustus 2019

Zuhdi, R. (2011). Makna Informasi Akuntansi sebagai Dasar Pengambilan Keputusan Bisnis di Usaha Kecil dan Mikro (UKM). Jurnal Akuntansi Multiparadigma, 2(3), 446-458. 